Searching for the ways of the effective work with the specialized texts is the key to solve the problems of the communicative competence of the students and cadets. The choice of the text material and the suitable system of exercises concerning the sphere of the professional speech contribute to the purposefulness of learning the foreign language and raising its motivation. One of the most efficient types of work that help to form the skills and abilities of the professional speech is the discussion that makes it possible for the educational process to become more dynamic and teaches the students and cadets the creative process of the professionally oriented language cognition.

\title{
References:
}

1. Гапонова B.M. Методичні аспекти навчання мови для професійної комунікації. Збірник наукових пращь. Хмельницький: Видво Нац. акад.. ПВУ, 2002. Ч. ІІ. № 21. С. 118-124.

2. Зеленська О.П. Комунікативний підхід до навчання читання спеціальної літератури англійською мовою. Збірник наукових праџь. Хмельницький: Вид-во Нац. акад.. ПВУ, 2004. Ч. II. № 27. С. 70-73.

3. Морозова И.Г. Использование дискуссии на занятиях иностранного языка в рамках проблемного обучения при подготовке современных специалистов. Иностранные языки. Теория и практика. 2010. № 1. C. 25-35.

DOI https://doi.org/10.30525/978-9934-26-114-5-49

\section{ҒАСЕВООК ЯК ПЛАТФОРМА АУДИТОРНОГО/ДИСТАНЦІЙНОГО ВИКЛАДАННЯ/НАВЧАННЯ (ОСОБИСТИЙ ДОСВІД 2018-2021 РОКІВ)}

\author{
Корніснко О. В. \\ кандидат психологічних наук, дочент, \\ дочент кафедри психодіагностики та клінічної психології, \\ факультет психології \\ Київький національний університет імені Тараса Шевченка \\ м. Київ, Україна
}

Представлений матеріал тез має на меті познайомити викладачів, науковців, студентів, докторантів, відповідальних працівників освіти психолого-педагогічного спрямування з особистим досвідом викладача 192 
який за тривалий період професійної діяльності 1994-2021 років постійно знаходився у творчому пошуку удосконалення методів викладання психологічних дисциплін на факультеті психології КНУ імені Тараса Шевченка. За рекомендаціями колег створив власний аккаунт у Facebook y 2017 році. Загальна кількість друзів 1654 осіб [1] Підходив до цього питання виважено враховував те, що маю запрошувати до спілкування студентів, аспірантів, докторантів, психолого-педагогічних працівників України та зацікавлених осіб 3 різних регіонів світу.

Вважаємо за доцільне коротко розкрити етапи впровадження сучасних навчальних технологій. На факультеті психології Національного університету імені Тараса Шевченка впроваджувалась очнодистанційна концепція впродовж 2006-2009 років на прикладі викладання декількох дисциплін: «Безпеки життєдіяльності» - студентам першого, третього курсів факультету психології, відділення соціальної роботи, соціологів та психологів; «Методи підтримання психосоматичного здоров'я» - третього курсу психологам (українською/англійською мовою); «Практикум з психології особистості» (на прикладі авторського курсу - психосоматичне здоров'я особистості, методи оцінки та підтримання) - другого курсу психологам; «Загальна психологія» четвертого курсу радіофізичного факультету; «Психологічна допомога у надзвичайних ситуаціях» - спеціалістам, магістрам та військовим психологам-курсантам (українською/англійською мовою) [2, с. 50-53]. Навчання проводилося 3 урахуванням поєднання аудиторного та дистанційного навчання. Особливістю дистанційного навчання було те, що викладач організував систематичний інтерактивний діалог зі студентами через електронну пошту. Кожна студентська група мала спільну електронну адресу для отримання від викладача основних навчально-методичних матеріалів, завдань та рекомендацій. Студенти в свою чергу підтримували зв'язок 3 викладачем через надсилання результатів виконаних домашніх завдань через електронну пошту. Перевагою даного підходу було те, що відкрилась можливість приділяти більше часу студентам поза навчальних аудиторних годин, студенти, також, отримали можливість у зручний час взаємодіяти 3 викладачем, отримувати консультації під час вивчення базових дисциплін.

За останні роки над впровадженням нових навчальних технологій працювали різні фахівці, наприклад, у статті [3, с. 38-42] «Дистанційна освіта: організаційна структура, психолого-педагогічні основи, фінансування і управління» розглядаються базові вимоги, щодо розробки навчально-методичних матеріалів, що потребує врахування 
психологічних закономірностей сприйняття, пам'яті, мислення, уваги, а також, вікових особливостей студентів. У наступній роботі двох авторів [4, с. 199-203] «Електронне дистанційне і комбіноване навчання у львівських вищих освітніх закладах» проводиться огляд організації навчального процесу з впровадженням дистанційної форми навчання у декількох вузах: Львівського національного університету імені I. Франка, Національного університету «Львівська політехніка», Університету «Львівський Ставропігіон», Української академії друкарства, Львівської комерційної академії, Львівського регіонального інституту державного управління Національної академії державного управління (НАДУ) при Президентові України, а також Науково-технічного центру учнівської молоді Шевченківського району м. Львова.

Повертаючись до основної мети представлених тез фокусую увагу читачів на те, що особисто було зроблено автором та студентами при викладанні та вивченні базових дисциплін з застосуванням платформи Facebook впродовж 2018-2021 років. Разом зі студентами було прийнято рішення поєднувати аудиторне та дистанційне навчання. Всього за вказаний період було створено на власній сторінці Facebook 22 начальних груп 3 включенням відповідних назв дисциплін які вивчали студенти, з виділенням курсу та року навчання, особливостями навантаження викладача. Були, також, ініціативно створені групи психолого-профілактичного спрямування з метою підтримання психосоматичного здоров'я студентів, співробітників факультету.

Пропоную учасникам міжнародної наукової конференції 16-17 липня м. Рига Латвія оцінити результати навчальної діяльності студентів та викладача здійснивши простий та доступний вхід через відповідне посилання до результатів навчальної діяльності на сторінках Facebook: [5], [6], [7], [8], [9], [10], [11], [12], [13], [14], [15], [16], [17], [18], [19], [20], [21], [22], [23], [24], [25].

3 очікуванням на пошук однодумців та прихильників аудиторнодистанційного навчання, встановлення продуктивного співробітництва, розширення міжособистих контактів, участі у дистанційних навчаннях, підвищення професійно-орієнтованих знань, умінь, навичок.

\section{Література:}

1. Корнієнко O.B. https://www.facebook.com/ovkdefender/

2. Корнієнко О.В. Концепція та перспективи викладання інтегративного курсу «Безпека життєдіяльності « на факультеті соціології та психології // Вісн. Київ. ун-ту. Соціологія. Психологія. Педагогіка. 1999. - Вип. 7. - С. 50-53. 
3. Малінко О. «Дистанційна освіта: організаційна структура, психолого-педагогічні основи, фінансування і управління.» //Директор школи, ліцею, гімназії. - 2002. - № 6.-С. 38-42

4. Коваль М., Шуневич Б. Електронне дистанційне і комбіноване навчання у львівських вищих освітніх закладах // Педагогіка i психологія професійної освіти: Науково-методичний журнал. - 2006. № 1. - С. 199-203.

5. Прихильники та противники психоаналізу».Третій курс психологи, 2018 - https://www.facebook.com/groups/819733314896068

6. Нейрографіка Павла Пискарева. Другий курс психологи, 2018.- https://www.facebook.com/groups/569789380056513

7. Нейропсихологія в психосоматичному здоров'ї студентів. Другий курс психологи, 2018.- https://www.facebook.com/groups/ 191193754821747

8. Напрямки сучасної психотерапії. Магістри психологи. Перший курс, 2018.- https://www.facebook.com/groups/2151089308441435

9. Second year psychologist. Video presentations «Psychodiagnostics», 2018. - https://www.facebook.com/groups/1921626907879014

10. English-speaking psychologist group. Second year psychologist, 2018.- https://www.facebook.com/groups/1921626907879014

11. «Психодіагностика». Менеджмент організацій, четвертий курс психологи, економічний факультет, 2019 - https://www.facebook.com/ groups/1403859769767899

12. «Психодіагностика». Економічна кібернетика, четвертий курс психологи, економічний факультет, 2019 - https://www.facebook.com/ groups/599706097439710

13. «Загальна психологія».Військові психологи, другий курс, 2019 https://www.facebook.com/groups/2476271799318549

14. Прихильники інформаційних проектів вузів України https://www.facebook.com/groups/1061936250986118

15. «Безпечний літній відпочинок. Психосоматичне здоров'я. Фактори ризику», 2019.-https://www.facebook.com/groups/638470 649991543

16. Clinical Psychopharmacology. Magistracy correspondence psychologists, first year, 2019-https://www.facebook.com/groups/ 2277948662524072

17. «Психодіагностика», психологи заочники другий курс, 2019. https://www.facebook.com/groups/621724758274184

18. «Психодіагностика», психологи заочники другий курс, 2020. https://www.facebook.com/groups/655037178674797 
19. «Альтернативні методи підтримання психосоматичного здоров'я», 2020 - https://www.facebook.com/groups/691374335046543

20. «Клінічна психологія». Курсанти-психологи, третій курс, 2020. https://www.facebook.com/groups/288651000811635

21. «Психодіагностика», третій курс, соціальна педагогіка, 2020. https://www.facebook.com/groups/790563511690921

22. Психолого-педагогічна громадськість України та домашні улюбленці, 2020.- https://www.facebook.com/groups/282344725944301

23. «Медична психологія», третій курс медики, Інститут Біології та Медицини, КНУ Тараса Шевченка, 2020. https://www.facebook.com/groups/2271955993097037

24. «Medical Psychology», third year medical foreign students, Institute of Biology and Medicine, KNU named after Taras Schevchenko.https://www.facebook.com/groups/522233258413026

25. Безпека психосоматичного здоров'я молоді в Інтернеті, 2021. https://www.facebook.com/groups/471083360933240

26. Група прихильників оздоровчо-тренувального плавання факультету психології КНУ імені Тараса Шевченка, 2019 https://www.facebook.com/groups/358897828025722/

DOI https://doi.org/10.30525/978-9934-26-114-5-50

\title{
СПОСОБИ ВДОСКОНАЛЕННЯ КОМУНІКАТИВНОЇ КОМПЕТЕНТНОСТІ ВИКЛАДАЧА ЗВО
}

\author{
Кучерова О. О. \\ кандидат філологічних наук,
}

доиент кафедри англійської мови факультету гуманітарних наук

Національний університет «Києво-Могилянська академія»

Нестеренко Л. О.

кандидат наук з державного управління, доцент,

дочент кафедри англійської мови факультету гуманітарних наук

Національний університет «Києво-Могилянська академія»

м. Київ, Украӥна

Аналіз наукових праць $[1,3,4,7,8]$ свідчить, що комунікативна компетентність викладача ВНЗ - це інтегральний показник, що характеризує якість розвиненості складних комунікативних навичок та здатність особистості викладача адаптуватися до нових суспільних 